\title{
The Implementation of Religious Humanistic Pedagogy to Building Student Character
}

\author{
Anas Salahudin, Yayan Carlian, Dede Rohaniawati \\ Department of Islamic Primary Education \\ UIN Sunan Gunung Djati \\ Bandung, Indonesia \\ anassalahudin@uinsgd.ac.id, yayan.carlian@uinsgd.ac.id, \\ dede.rohaniawati@uinsgd.ac.id
}

\author{
Neng Gustini \\ Department of Management Islamic Education \\ UIN Sunan Gunung Djati \\ Bandung, Indonesia \\ neng.gustini@uinsgd.ac.id
}

\author{
Hilman Mangkuwibawa \\ Department of Islamic Early Childhood Education \\ UIN Sunan Gunung Djati \\ Bandung, Indonesia \\ hilman.mangkuwibawa@uinsgd.ac.id
}

\begin{abstract}
This study presents the concept of humanisticreligious pedagogy to developing the character of students and application in learning. Pedagogic as a science that especially educates children is very strategic given to be studied, either by a teacher at the elementary level of education of elementary and higher education. Pedagogical understanding is very important for all educators. Knowing theoretical and practical pedagogy can optimize the learning objectives. Humanistic pedagogy promotes students as creatures with potential and based on selfevolving needs to contribute to society and the world. In the application of humanistic pedagogy, the educator still provides guidance, manages the class and seeks the learner to engage in meaningful activities that will make him a skilled person and have a good attitude developed through learning activities. The purpose of this study is to explain the concept of humanisticreligious pedagogy in developing the character of learners and application in learning. The approach used is qualitative and the method is qualitative descriptive. The results show that humanistic-religious pedagogy is an alternative national education paradigm for the development of students' character as a whole, which has an impact on improving the quality of education.
\end{abstract}

Keywords—character; humanistic religious; islamic education

\section{INTRODUCTION}

Humanistic education is an educational theory that makes humanism an approach [1]. In the approach of religious humanism, education is based on an approach to God through human experience. Although there are similarities with secular education, religious education has added value. This value is the advantage, these values are spiritual values that are used to manifest the real people as the direction of humanistic education in Islam. Baharuddin and Moh. Makin argues that humanistic education aims to form human beings as individuals who are committed to being truly human beings; who have the awareness, freedom, and responsibility as individual human beings, and realize that he lives in the community. A man has a moral responsibility to the environment in the form of a desire to devote himself to the good of society [2]. Thus, the humanist pedagogical role of promoting human values in humanizing human beings is essential in providing profound interpretation of the diversity bases as a social reality that must be accepted by every human being [3]. As research conducted by L. Philips Barnes on the study of humanism in Religious Education [4], a study by Abur Hamdi Usman, et al on Humanism in Islamic Education which implements Islamic humanism in Education. Especially Islamic Education as an integral part of National education so that both goals are achieved, both the goals of National education as well as the goals of Humanistic Education are not contradictory to each other [5] as well as research conducted by Shaynah Neshama-Bannister on the pedagogy paradigm for the integration of religion and spirituality in Social work education aimed at implementing pedagogies for religious and spiritual learning in Higher Education [6].

\section{METHOD}

This research is a research library with the analytical descriptive form with a qualitative approach. The qualitative approach is used because the focus of the research is the conceptual part of the humanistic-religious concept of human thought-thinking $\mathrm{Ki}$ Hajar Dewantara and Abdurrahman Mas'ud. Therefore, the data to be collected is the data library that is representative and relevant to the object of study. 


\section{RESUlT AND DisCUSSION}

Pedagogy by the philosophical review is an assumption derived from a philosophy that is used as a starting point in education [7]. The idea of a general philosophy consists of metaphysics, epistemology, and axiology. Mudyahardjo argues, pedagogic philosophically as a comprehensive critical analysis of education as one form of educational theory produced through research, both quantitative and qualitative [8]. There are three types of influential educational philosophy: idealism, realism, and pragmatism. The theory of humanistic education emerged in the 1970s based on three philosophical theories, namely: pragmatism, progressivism, and existentialism [9]. The core of pragmatism in humanist education that learners are subjects with experience. He is an intelligent individual who can solve problems. The idea of progressivism in humanism is strongly influenced by a pragmatism that emphasizes the freedom of self-actualization for learners to be creative, they emphasize the fulfillment of the needs and interests of children, children must be active in building life experiences. While existentialism Sartre puts the man in his position as himself and puts the overall responsibility of his life completely to himself. Theory of existentialism emphasizes the uniqueness of the child individually rather than progressivism that tends to understand the child in the social unit. Children as unique individuals. This view of the uniqueness of the individual leads humanists to emphasize education as the search for personal meaning in human existence [10]. Initially, humanism is a literary, cultural, though, and education, then developed and entered in politics. In other words, consciously or not, humanism has entered into all aspects of society, such as communism, utilitarianism, spiritualism, individualism, existentialism, liberalism, to the Protestantism of Martin Luther King (Protestant Christianity). Modern philosophy developed in the West explains that humanism has positioned man as the center of all activity, and all life implications are determined by man himself and there is no intervention of God because in principle humanism in the West cannot be separated from materialism that does not recognize things that are spiritual. In this way, the existence of God as a spiritual part does not have a proper place in the study of Western philosophy, including the flow of humanism that grows and develops in the West looks very anthropocentric.

The essence of humanism is to uphold the glory of man, not to humiliate him into a materialistic person. Real humanism is only one, the humanism that makes the vertical dimension (belief in God) as a backdrop to provide a guarantee of human values [11]. According to Boisard in L'Humanism de l'Islam, the teachings of religion affect human nature and perceptions which further determine his position, the priority of needs and the formation of rules of relationship with other humans [2]. It is clear that the view of humanism is divided into secular (western) humanism and religious humanism. Both secular humanism (western) and religious humanism generally share the same view and share the same principle of defending the identity of the man, which distinguishes religion. Humanism is principally materialistic and denies religion, whereas religious humanism integrates religion. So it can be understood that humanistic-religious pedagogical education is appropriately used in developing the character of learners as a homo educandum because it corresponds to the philosophy of humanity in humanistic education that recognizes human value and value and makes it the basis or measure of the judgment of all things. As well as Afsaruddin explains Gülen's view that the humanistic approach is not only science but the overall Education which reflects the pattern of classical education in the Islamic world. Gulen added that this approach includes humanism, religion, ethics and traditional cultural values. This opinion is reinforced by research conducted by Abur Hamdi Usman, et al, which explains that the orientation of the educational system in the Islamic Education institution begins with theocentric philosophy. Through the Education process, learners intensively review Islamic learning and practice comprehensively. Islamic learning explicitly describes the practice of Islam in the context of Islamic humanism which emphasizes moral goodness, unity, and brotherhood and implements freedom in the Muslim character as the main pillar of Islamic humanism in Islamic educational institutions. Humanism in the context of philosophy, man is seen as a measure of every judgment, and the main reference of every event in the universe. One of the assumptions underlying this philosophical view is that man in principle is central to reality. So in this philosophical, it says that everything is judged and the ultimate reference of all human events is returned to himself, not to forces outside of man (e.g., the power of God or nature) [1].

This humanistic education has advantages and disadvantages. The disadvantage is that if we use humanistic education in developing the character of learners by referring to the understanding of western humanism, then human (learners) will tend to be materialistic and deny the religion (God) because of the value and the human dignity as the basis and the measurement of all things. However, if this humanistic pedagogy is combined with the religious, then in the development of the human character of the learner will involve God (religion) in understanding and practice, while human values and values are not the only ones. This opinion is reinforced by Abur Hamdi Usman et al (2017) research that the implementation of humanism in Islamic education is an urgent need and provides a vital educational role in the development of the culture of society and individuals. In the context of formal education, education consists of several aspects, including teachers, learners, methods, teaching materials or tools and evaluation. In the context of Indonesia, the foundation for the realization of humanist society as stated in Pancasila, that is just and civilized humanity is an institutional guarantee that fortifies human rights. The concept of human rights where the idea of the importance of returning to monotheistic religious beliefs stating that in the eyes of God all humans have in common the dignity. God has given them a privileged position among God's other creatures [8].

\section{CONCLUSION}

Humanistic-religious pedagogy is an alternative national education paradigm for the personal development of learners as a whole, which has an impact on improving the quality of education. The character of learners as a child of the nation is reflected in the strength of values, both moral and religious values and science and technology as strengthening the ability 
to improve competitiveness. Therefore, national education should be led to a humanism-religious paradigm to educate the nation's children toward the golden generation with strong character and personality. And this condition is supported by policies, management, curriculum, and other components of education that work together synergistically for the creation of characterized education personnel.

\section{ACKNOWLEDGMENT}

The authors would like to thank Indonesia University of Education lecturers in Bandung city, especially in the department of Counceling postgraduate who has contributed and this paper can be completed.

\section{REFERENCES}

[1] Z. Abidin, Konsep Humanis dalam Pendidikan Islam, 8th ed., vol. 1. UIN Sunan Ampel: Surabaya, 2000, pp.26.
[2] M.A. Boisard, Humanisme dalam Islam. Bulan-Bintang: Jakarta, 1980.

[3] Baharudin, and M. Makin, Pendidikan Humanistik: Konsep, Teori, dan Aplikasi dalam Dunia Pendidikan. Ar-Ruzzz Media: Yogyakaarta, 2011.

[4] L.P. Barnes, Humanism, Religious education and The Former Archbishop of Canterbury, vol.119 (1). Sagepub, 2016, pp. 18-25.

[5] A.H. Usman, dkk. Humanism In Islamic Education: Indonesian References. Vol 13 no. 1.IJAPS, 2017, pp. 95-113.

[6] S.N. Bannister, Worldview Pedagogy for Integration of Religion and Spirituality in Social Work Education. Vol 1 no. 1. Sciedu Press, 2016.

[7] R. Mudyahardjo, Filsafat Ilmu Pendidikan. Remaja Rosdakarya: Bandung, 2006.

[8] A. Multazam, Pendidikan Islam Berbasis Humanisme Religious. UIN Walisongo: Semarang, 2015.

[9] M. Rahman, Pemikiran Pendidikan Humanistik dalam Islam, 8th ed., vol. 2. UIN Walisongo: Semarang, 2013, pp.162.

[10] J.P. Sartre, Eksistensialisme dan Humanisme, Pustaka Pelajar: Yogyakarta, 2002.

[11] S.S. Pettalongi, Islam dan Pendidikan Humanis dalam Resolusi Konflik Sosial, 32nd ed., vol. 2. UNY: Yogyakarta, 2013, pp.173. 